\title{
1. The European Commission and Europe 2020: smart, sustainable and inclusive growth
}

\section{Daniel Silander}

This book focuses on European political entrepreneurship in the Europe 2020 strategy. The aim of the book is to analyse the Europe 2020 strategy and the role of European political entrepreneurship in debating, shaping and implementing the strategy within the EU's political levels of governance. In 2010, the European Commission released an official communication titled 'Europe 2020 - A strategy for smart, sustainable and inclusive growth'. It succeeded the European Single Market programme (1986-92) and the Lisbon Strategy (2000-10) and was decided on by the European Council at a meeting on 26 March 2010, chaired by President Herman Van Rompuy. The Lisbon Strategy aimed to transform Europe into the most competitive economy in the world, but it was more or less a failure due to an overloaded agenda, lack of member state commitment, lack of ownership and political steering, conflicting priorities and the 'one-size-fits-all' strategy in a socioeconomically and politically heterogeneous Europe (Stec and Grzebyk, 2018: 120-22; Fura et al., 2017: 969; see also Kotz, 2005; Erixon, 2010; European Commission, 2010). In the new Europe 2020 strategy, the Commission called upon EU institutions, member states, regional and local authorities and the private sector to address the economic crisis (Wandel, 2016: 10; Zeitlin and Vanhercke, 2014: 8-9) by promoting smart, sustainable and inclusive growth. It referred to smart growth as promoting an economy based on knowledge and innovation, sustainable growth as economic growth based on resource efficiency and a greener economy and inclusive growth as growth that provides for social integration. The Commission further argued that fundamental measures, beyond day-to-day and regular political and economic activities, had to be implemented by engaged European actors seeking new economic and social models and presenting the state of the world, on all political levels of European governance (see Silander, 2018; Barbier, 2011). From 1995 and up to 2010, the Commission and member states had played different 
powerful roles as driving engines behind socioeconomic reforms (see Barbier, 2011: 13-17). However, in 2009-10, the Commission pushed for Europe 2020 and the idea of EU governance. It was stated how the European Council had 'full ownership' of the Europe agenda, how the Commission would 'monitor progress towards the targets', and how the European Parliament should 'mobilise citizens and act as co-legislator on key initiatives', but also how the strategy had to engage EU committees, national parliaments and local and regional authorities 'in delivering on the vision' (all cited in European Commission, 2010: 4).

In addition, the crisis was argued to be a wake-up call for the EU and an alarming signal that business as usual would lead the EU along with member states into further recession and to the second rank in the new global economic order. However, a European crisis could also serve as an opportunity for European integration as had been the case throughout the many decades of European politics (see Cross, 2017). This time, the EU had to engage new, innovative politics and to be bold and ambitious by showing leadership and entrepreneurship to determine Europe's future. In 2010 the former chair of the Commission, José Manuel Barroso, called for what this study refers to as European political entrepreneurship by politicians, bureaucrats, officers and institutions within the publicly funded sector. With innovative approaches, political entrepreneurship encourages entrepreneurship towards a goal of growth and employment for the common good (see Karlsson et al., 2016; 2018; Silander and Silander, 2015). As stated by the former Chair of the Commission,

The condition for success is a real ownership by European leaders and institutions. ... European leaders have a common analysis on the lessons to be drawn from the crisis. We also share a common sense of urgency on the challenges ahead. Now we jointly need to make it happen.... We must have confidence in our ability to set an ambitious agenda for ourselves and then gear our efforts to delivering it. (Barroso, 2010: preface)

\section{POLITICAL ENTREPRENEURSHIP}

A large bulk of studies in economics have for more than half a century stressed how entrepreneurship and entrepreneurs are vital aspects of a growing and dynamic economy (see Schumpeter, 1934; Kaiser, 1990; Carroll, 2017). In the academic literature entrepreneurship plays a crucial role for growth by focusing on entrepreneurs as the important risktakers, innovators and responders to market disequilibria and so on. Although research on entrepreneurs and entrepreneurship has mostly taken place within economics, there has been a growing bulk of studies 
on entrepreneurial activities in the public sector. Such a growing body of literature has been inspired by core elements of entrepreneurs and entrepreneurship from the business sector such as the importance of knowledge, innovation, opportunity, implementation and risk-taking (see discussion by Carroll, 2017: 115-19; see also Jones, 1978). Europe 2020 also calls for immediate innovative, risk-taking political actions to seek new opportunities to improve the conditions for entrepreneurship and growth in Europe.

Although the concept of a public entrepreneur had already been identified in 1965 (see Ostrom, 1965), it took about three decades until the concept of entrepreneurship in the public sector was further developed in academia (for example, see Osborne and Plastrik, 1993; Baumol, 1990). Studies have identified public entrepreneurs as innovative and creative actors within municipalities and public corporations who seek implementation of innovations in the public sector practice (Ostrom, 1965; Roberts and King, 1991). Studies have also pointed out social entrepreneurs are innovative and goal-oriented citizens with the objective of promoting normative good that does not have to be economically oriented, but rather they can have social goals in cooperative associations, interest organizations and movements and so on (Gawell et al., 2009; Borzaga et al., 2008; Brickerhoff, 2000). Such normative good could be to improve welfare services for the young and the elderly, promote human rights issues, work for sustainable development or organize sports and leisure. In addition, policy entrepreneurs have often been used as a description of actors outside the formal positions of government who seek to introduce and implement new ideas into the public sector (Roberts and King, 1991) or for politicians and/or government employees who see a window of opportunity to improve government policies. Policy entrepreneurs may or may not be formally or directly engaged in legislative policymaking, but based on know-how, reputation, money and time, they are in a position to develop and present alternative policy solutions to existing problems facing policymakers (Kingdon, 1995). Finally, another concept of entrepreneurship has been the bureaucratic entrepreneur, referring to actors as public servants or similar who gain power from policymakers to influence the policy process by initiating a political process, setting priorities and interpreting the implementation phase and so on (Silander, 2016: 11-12; Carroll, 2017; Nakamura and Smallwood, 1980; Roberts and King, 1991).

The different types of conceptual approaches to entrepreneurship are summarized in Table 1.1. Many different types of entrepreneurs and entrepreneurship are described in the literature, and the definitions of these types have differed from one study to another. This has led scholars to argue that "perhaps the largest obstacle in creating a conceptual 
Table 1.1 Types of entrepreneurs

\begin{tabular}{|c|c|}
\hline Term & Common Definitions \\
\hline Econ & Actors within the business sector acting as risk-takers, \\
\hline Entre & $\begin{array}{l}\text { innovators and responders to market disequilibria to } \\
\text { seek economic gains for their companies/organizations }\end{array}$ \\
\hline Social Entrepreneurs & $\begin{array}{l}\text { Actors within the civil society who seek societal } \\
\text { changes within cooperative associations, interest } \\
\text { organizations, aid branches and rights and liberties } \\
\text { movements }\end{array}$ \\
\hline Policy Entrepreneurs & $\begin{array}{l}\text { Actors inside or outside the formal positions of } \\
\text { government/politics who seek to introduce and } \\
\text { implement new ideas into the public sector for } \\
\text { development of the public good rather than for } \\
\text { individual profits }\end{array}$ \\
\hline Public Entrepreneurs & $\begin{array}{l}\text { Actors within public corporations within the public } \\
\text { sector who seek implementation through innovations } \\
\text { in public sector practice }\end{array}$ \\
\hline Bureaucratic & Actors who gain power from policymakers to influence \\
\hline Entrepreneurship & $\begin{array}{l}\text { the policy process and/or the public sector by initiating } \\
\text { a political process, setting priorities and interpreting } \\
\text { the implementation phase }\end{array}$ \\
\hline $\begin{array}{l}\text { Political Entrepreneurs } \\
\text { - traditionally used }\end{array}$ & $\begin{array}{l}\text { Actors (politicians) within the political arena, driven } \\
\text { by the common good or individual profit from the } \\
\text { political system, acting to receive political support, } \\
\text { votes, campaign contributions or improved political } \\
\text { status }\end{array}$ \\
\hline $\begin{array}{l}\text { Political Entrepreneurs } \\
\text { - applied in this study }\end{array}$ & $\begin{array}{l}\text { Actors and institutions (politicians, bureaucrats, } \\
\text { officers and institutions) within the publicly funded } \\
\text { sector that with innovative approaches encourage } \\
\text { entrepreneurship/business and where the goal is growth } \\
\text { and employment for the common good }\end{array}$ \\
\hline
\end{tabular}

framework for the entrepreneurship field has been its definition. What the many different studies on types of entrepreneurship have in common is the main focus on how entrepreneurship includes knowledge, innovation, opportunity, implementation and risk taking as core elements' (see Carroll, 2017: 115). But what has differentiated private/business and public sector entrepreneurs and entrepreneurship has been the lack of entrepreneurial profit (see Boyett, 1996: 49) in public sector entrepreneurship.

In more recent studies, the developing multidisciplinary approach to entrepreneurship has also referred to political entrepreneurs and political entrepreneurship (Silander, 2016; 2018; Silander and Silander, 2015; 
Scheingate, 2003). Such conceptualization was introduced by Robert Dahl, who focused on resourceful and masterful political leaders and how the political entrepreneur was 'the epitome of the self-made man' (1974: 25, 223-7, 282). According to Dahl, Homo politicus are people formally engaged in politics. Political entrepreneurs could be driven by the common good and by providing collective benefits to the many, but they could also be oriented towards individual profit seeking from the political system by, for instance, receiving political support and votes, campaign contributions or improved political status (see Dahl, 1974; McCaffrey and Salerno, 2011; Simmons et al., 2011). In Dahl's discussions, individual leaders have often been referred to as entrepreneurial politicians (Scheingate, 2003), but others have used political entrepreneurship to refer to individuals trying to individually profit from the political system (see McCaffrey and Salerno, 2011).

This study focuses on European political entrepreneurship in the Europe 2020 strategy, but conceptualizes political entrepreneurs and political entrepreneurship based on existing criticism of previous research. First, it has been argued that studies on political entrepreneurship have focused on political entrepreneurs from an actor-oriented perspective by only analysing individual motives and perceptions with institutions as a forgotten dimension. Second, such studies have often started from the assumption that political entrepreneurship is about individual profit-seeking activities within the political/public system, rather than the common good. Third, it has also been argued that fuzzy distinctions have been made between what actually defines political entrepreneurship; that is, what political entrepreneurship is all about compared to regular, day-to-day political/ public activities in the public sector. From a political entrepreneurship perspective, studies have focused on how politicians and bureaucrats may change tax distribution, regulations and implementation procedures, but they have forgotten to argue for why such regular activities in politics would be defined as political entrepreneurship or not (Salerno, 2008; Scheingate, 2003; Holcombe, 2002; Schneider and Teske, 1992).

Following recent studies on political entrepreneurs and political entrepreneurship (see Karlsson et al., 2016; 2018; Silander and Silander, 2015), our perspective focuses on politicians, public servants, bureaucrats and institutions that seek to create new, innovative and favourable formal and informal institutional conditions (see North, 1990; see also Kingdon, 1995) for growth and employment. Political entrepreneurship is about approaching and challenging traditional formal institutions in political steering, leadership, strategies, policies, rules, regulations, laws and budgets for entrepreneurial activities and/or in traditional informal institutions' ideas, attitudes, values, perceptions, images and symbols in ways that 
structure public day-to-day activities and culture around entrepreneurship (see North, 1990; Morgan, 1986; Putnam, 1993; Casson, 1995; Finnemore and Sikkink, 1998; McCaffrey and Salerno, 2011: 553). Political entrepreneurship occurs when traditional institutions, formal and/or informal, are challenged and changed by new institutions, formal and/or informal, better suited to promote entrepreneurial activities and economic growth. As argued in a previous study, 'The political entrepreneur operates beyond traditional and routinized procedures and is innovative and creative in using formal and informal institutions and networks to improve the public sector's activities towards entrepreneurs and entrepreneurship by developing and promoting new norms that have not been embedded in traditional day-to-day public activities' (Silander, 2016: 10).

\section{EU GOVERNANCE AND EUROPE 2020}

The Commission has set out how the European Council must play the role of guiding the EU member states towards the objectives set out in Europe 2020. The European Council should steer the work on Europe 2020 as the political body that could promote integration and collaboration and ensure member state interdependence and collaboration between the EU and member states. On the other hand, the Council of Ministers should be responsible for the implementation of Europe 2020 and making sure that all objectives are met. The progress made by member states with regional and local authorities would be monitored and assessed annually by the European Commission to ensure the development of smart, sustainable and inclusive European growth. It would also be the role of the Commission to set out policy recommendations, warnings and proposals based on these assessments of individual member states. The European Parliament would be co-legislator with the Council of Ministers, but also mobilizer of European citizens into the agenda, and it would have national parliaments include debate over how Europe 2020 could be implemented in the best way possible on a national level as well as regional and local levels, including domestic authorities in relation to private actors and the civil society (European Commission, 2010: 26-7).

All national, regional and local authorities should implement the partnership, closely associating parliaments, as well as social partners and representatives of civil society, contributing to the elaboration of national reform programmes as well as to its implementation. By establishing a permanent dialogue between various levels of government, the priorities of the Union are brought closer to citizens, strengthening the ownership needed to deliver the Europe 2020 strategy. (European Commission, 2010: 28) 
Multiple actors have been involved in the Europe 2020 strategy because of the nature of the EU as an organizational hybrid of international and supranational decision making and steering. Over decades, the EU has widened and deepened, and today EU politics is conducted on different levels of authority and networks, formally including political authorities on a European, national, regional and local level, together creating European governance. The EU has embedded top-down and bottom-up political policies to communicate between the national and local. The most obvious political symbol of EU governance has perhaps been the transfer of sovereignty from sovereign individual member states to the EU institutions. Over time, the EU has become a significant political power in individual member states' politics (Hix and Goetz, 2000). This has been the case foremost in policy areas where the EU has received supreme authority, but the EU has also influenced policy areas where shared competence and supporting competence has existed.

Based on the Treaty of Lisbon of 2009, the EU with member states has a division of competences (Lisbon Treaty, 2009). The Treaty explicitly sets out EU competences and therefore policy areas not mentioned in the Treaty are under the sovereignty of each member state. The Treaty identifies three main categories: exclusive competences, shared competences and supporting competences.

First, exclusive competences are mentioned in Article 3 of the Treaty of Lisbon on the Functioning of the European Union (TFEU), which sets out areas where the EU is the supreme authority to legislate and adopt binding acts. The individual member states have transferred all sovereignty to the collective will of the EU, and member states are only involved in decisions when they are called upon by the EU to implement policies. The Commission initiates and implements laws and regulations based on the authorities in the Treaty. In addition, the Council, the Parliament and the European Court assess the rights of the Union in relation to what the Treaty says. The EU possesses exclusive competence on the customs union, the establishment of competition rules in the internal market, monetary policy for the euro area, conservation of marine biological resources under the common fisheries policy, common commercial policy and international agreements (EUR-Lex: Distribution of competences, 2018).

Second, shared competences are institutionalized in Article 4 of the Treaty of Lisbon and refer to where the EU and member states share authority to legislate and adopt legally binding acts. Individual member states are sovereign to decide and legislate if the EU has not exercised authority or has addressed intention to exercise authority. Additionally, in those cases when individual member states have laws and regulations in place, the EU has no authority to decide on laws and regulations that 
could harm or challenge existing national regulations. Shared competence is exercised in the

internal market, social policy (specifically defined in the Treaty), regional policy, agriculture and fisheries (except conservation of marine biological resources), environment, consumer protection, transport, trans-European networks, energy, area of freedom, security and justice, shared safety concerns in public health matters (defined in the TFEU), research, technological development, space and development cooperation and humanitarian aid. (EUR-Lex: Distribution of competences, 2018)

Third, supporting competences are mentioned in Article 6 of the Treaty of Lisbon and delegate the main authority to the individual member states with the supporting role of the EU. The EU has no authority to act for harmonization of state policies, laws and regulation, but may only assist member states through coordination. Supporting competences refer to protection and improvement of human health, industry, culture, tourism, education, vocational training, youth and sport, civil protection and administrative cooperation (EUR-Lex: Distribution of competences, 2018). ${ }^{1}$

The Europe 2020 strategy covers a wide range of policy areas and therefore refers to all three categories of competence. Parts of the strategy are under the regulation of exclusive EU competence, whereas most parts are under shared or supporting competences. This leaves the Europe 2020 strategy to be decided on and implemented by several EU actors in the framework of European governance. ${ }^{2}$ The specific role of the EU only in policy areas designated as its exclusive competence has traditionally led to

1 The categories of competences portray the formal hybrid structure of the EU and the official way politics is handled. In day-to-day activities, however, these formal competences are often challenged by practical political hindrances. For instance, despite the EU's exclusive competence in specific policy areas, does the EU embed member states in the Council of Ministers and national politicians in the Parliament who have a say and decide on political issues and policies to be implemented by national politicians and public servants at home in the individual member states? In addition, in those policy areas where member states have full authority, is politics often influenced by the EU institutions due to the networks of local, national and European actors of official and unofficial ties?

2 The EU categories of exclusive, shared and supporting competences are rooted in two fundamental principles of the EU as set out in Article 5 of the Treaty. The first principle is proportionality and refers to how all EU actions must be proportional to the goals to be achieved (that is, EU actions must only be necessary). The second principle relates to subsidiarity and refers to how the EU in areas of non-exclusive competences must refer decision making to appropriate levels of authority. It requires the EU not to act in policy areas of non-EU competence, but only participate if EU member states are unable to reach identified goals and if such goals can be fulfilled on an EU level. This is regulated in Article 352. It is important to acknowledge that in those policy areas that are not explicitly mentioned in the Treaty, all competences are in the hands of the member states. To change competences from 
policymaking in the EU that is complemented by the use of 'soft' governance tools, in terms of benchmarking, recommendations on best practices and guidelines through the Open Method of Co-ordination (OMC) process. The OMC was initiated at the Lisbon meeting in 2000 together with the European Employment Strategy as a method for the EU to influence policy areas where member states had major national differences and/or where the EU had limited competences in terms of influence. The decision on OMC in Lisbon was a compromise between leaving member states with the main responsibility in a policy area and at the same time opening up for the EU to coordinate policies (EUR-Lex: OMC, 2018). The OMC has primarily been about the EU initiating benchmarking and exchanging best practice between member states based on the voluntary and intergovernmental mode of cooperation.

However, the OMC process leaves the Commission with substantial influence through the monitoring and agenda-setting role (see Silander, 2018). In addition, the Council of Ministers also plays a central role by setting the policy goals and guidelines by unanimity. The OMC process allows member states to submit annual reports on progress made, and all reports are commented on and evaluated by the Commission. Although the OMC process differs in content due to different policy areas, there are common steps: Step 1 is fixing the guidelines for the union combined with a timetable (what is to be completed in the short, medium and long term). Step 2 is to establish quantitative and qualitative indicators and benchmarks. Step 3 consists of translating the European guidelines into national and regional policies by setting specific targets and adopting measures for reaching such targets. Step 4 is periodic monitoring and evaluations organized as mutual learning processes (see EUR-Lex: OMC, 2018).

\section{SMART, SUSTAINABLE AND SOCIAL INCLUSIVE GROWTH}

In 2010, after a few years of economic recession globally and in Europe, the European Commission officially stated Europe 2020 - A strategy for smart, sustainable and inclusive growth. Europe 2020 was a strategic concept from the Commission on how to promote and protect European growth, jobs and social integration in times of political, economic and social challenges (see Stec and Grzebyk, 2018: 119-20; Liobikienè and Butkus, 2017: 299; Hoedl, 2011: 11-12; Walburn, 2010: 699). The Europe

individual member states to the EU level demands an approval by all member states and from the European Parliament and a new ratification of a treaty. 
2020 strategy stressed the importance of developing and consolidating a European social market economy model (see Chapter 2). This model had previously been stressed within the EU, but Europe 2020 re-emphasized the importance of such a model by focusing on smart, sustainable and inclusive growth (Budd, 2013: 274-6; Gros and Roth, 2012: 1-2; Hoedl, 2011: 12). The Europe 2020 strategic targets were: (1) employment; (2) research, development and innovation (R\&D); (3) education; (4) poverty reduction and social inclusion; and (5) climate change and energy. As stated,

The Europe 2020 strategy has been developed as the successor to the Lisbon Strategy as a long-term approach to dealing with structural weaknesses in Europe's economy. One aspect that is supposed to differentiate the Europe 2020 strategy from the Lisbon strategy is the concentration on five key specific targets. These five targets are supposed to be representative of the overall goal of smart, sustainable and inclusive growth. (Gros and Roth, 2012: 77)

The Europe 2020 strategy established main objectives to be reached, implementation tools for handling the serious structural economic weaknesses in the European economy, and ways to turn the European economic recession of 2010 into prosperity and growth in 2020 by focusing on major reforms for smart, sustainable and inclusive growth. As stressed by the Commission, 'Smart growth: developing an economy based on knowledge and innovation. - Sustainable growth: promoting a more resource efficient, greener and more competitive economy. - Inclusive growth: fostering a high-employment economy delivering social and territorial cohesion' (European Commission, 2010: 3).

First, smart growth, in developing an economy based on knowledge and innovation, refers to new know-how and technology as main drivers for a future prosperous European economy. The main themes identified would be innovation, education and digital society. Smart growth requires improved education, research and innovations to provide a skilled workforce and new products and services, but also innovative entrepreneurship and financial investments to identify new needs, demands, markets and so on. The Commission argued for greater spending on research and development and foremost targeting private investments by facilitating improved conditions for private sector research and development in Europe. The Commission further identified the importance of improving education, training and lifelong learning by promoting better reading competences and increased numbers of people with university degrees, improving the standards and status of European universities, and matching education with labour market demands. In addition, Europe had to improve its competitiveness in the digital society by reaching out to the 
fast-expanding demands for communication technologies and increasing investment of European societies in the Internet and providing for more Internet-based goods and services (European Commission, 2010: 9-10). Smart growth was planned to be implemented through targets on the thematic areas, one on $\mathrm{R} \& \mathrm{D}$ and two for education. These targets were to increase public and private investments in R\&D to 3 per cent of gross domestic product (GDP), reduce school drop-out rates to less than 10 per cent, and increase the share of the population in the 30-34 age group having completed tertiary education to 40 per cent or more (Eurostat, 2018a; see also Hudrliková, 2013: 1).

Second, sustainable growth, through a transition to a greener economy, refers to building a European economy of resource efficiency and sustainability and staying globally competitive based on new greener technologies. The main themes in focus would be climate, energy and mobility and competitiveness. This requires innovative European political entrepreneurship to foster competitive entrepreneurship, new businesses and networks and to promote a consumer culture that values resource efficiency and a greener low-carbon economy. The Commission stated the importance of continued open trade of exports and imports but also that Europe had to become more competitive and with higher productivity of partner states. Europe must also continue its early initiatives to become a global green economic actor by pushing for green technologies to safeguard resource efficiency. The push for green technologies would lead to fulfilled climate change goals, with significant decreased emissions, but would also open up for a transition to a new environmentally friendly economy of new innovations, products and services that all together would create new jobs and a growing economy. A transition to a greener economy would also lead to lowered costs for import of expensive oil and gas and would be beneficial for European security because of lowered dependency on specific foreign governments (European Commission, 2010: 12-13). Sustainable growth would be approached based on three climate change and energy targets. The so-called 20-20-20 targets set out by the EU include reducing greenhouse gas emission by 20 per cent, increasing renewable energy in gross final energy consumption by 20 per cent and increasing energy efficiency by 20 per cent. Such targets not only provide for important measures against ongoing climate change, but also provide new jobs in a transformed, greener economy with green products and services and makes the EU become a green, global competitive actor (Eurostat, 2017: 15).

Third, inclusive growth, with a high-employment economy providing economic, social and territorial cohesion and integration, refers to empowering Europeans by offering job opportunities, an improved labour 
market, lifelong training, education and social protection from poverty and marginalization to all of Europe and all Europeans regardless of age, gender and so on. The main themes to prioritize were employment and skills and fighting poverty. The Commission clearly stated in 2010 the challenge of demographic change in Europe with a future limited workforce beside an unemployment rate that is higher than in the US - about two-thirds of Europe's working-age citizens being employed compared to about 70 per cent in the US. The Commission further stressed challenges in economic and social marginalization of women, older workers and young people, all facing different hindrances to entering the labour market and/or finding opportunities for education and financial support for building and developing businesses and so forth. The Commission estimated that about 80 million Europeans had only low or basic skills, 80 million European faced the serious risk of poverty (among them 19 million children), and the grave consequences of unemployment and poverty in social exclusion and health inequalities. The Europe 2020 strategy should focus on growth and jobs to sustain and develop Europe's social market economy (European Commission, 2010: 16). Inclusive growth would be approached based on targeting employment, poverty and social exclusion. These targets were established to increase the employment rate to 75 per cent in the 20-64 age group and to prevent at least 20 million people from living under the threat of poverty and/or social exclusion (Eurostat, 2017: 15).

The different natures of these objectives were all embedded in the overall framework of promoting and protecting smart, sustainable and socially inclusive growth in Europe. It was argued in the 'Europe 2020' communication that smart, sustainable and social growth were interrelated and had to be focused at once and as a reinforcing strategy. For example, the Commission stated that smart growth in greener technologies, through research and development, also implied new and sustainable growth and social development and that educational improvements in the lower levels to higher education provided for employability and job creation, as well as social integration, reduced poverty and so on. It was argued that 'educational improvements help employability and reduce poverty - R \& $\mathrm{D} /$ innovation and more efficient energy use makes us more competitive and creates jobs - investing in cleaner technologies combats climate change while creating new business or job opportunities' (European Commission, 2010).

The Europe 2020 strategy set out the overall goals to be met by EU member states on a national and regional level and translated them into national contexts and objectives to be assessed. These overall objectives were to reach 7 per cent employment among people aged 20-64; secure 
3 per cent of the overall EU GDP invested in research and development; lower emission levels by 20 per cent compared to the overall European greenhouse gas emissions in the 1990s; provide renewable energy sources that account for 20 per cent of all energy supply; and increase energy efficiency by 20 per cent by focusing on climate change and energy reforms for a greener economy. In addition, the main objectives were also to improve education standards by pushing down early school leavers to below 10 per cent, support enrolment in higher education by aiming for 40 per cent of people aged 30-34 to have finished higher education, and reduce the number of those who face poverty and social exclusion by at least 20 million people (European Commission, 2010: 3; see also Renda, 2014: 4; Hudrliková, 2013: 450-60).

The objectives were to be reached within a 10 -year period of time with reforms taking place from 2010 to 2020 . The reforms were to be conducted on different European levels of governance with the main focus on EU governance in EU institutional actions, as well as with national-, regionaland local-level actions at the member state level. The Europe 2020 strategy implied numerous actions by numerous European actors framed by the objectives set out in the Europe 2020 plan and assessed by annual national reports to the Commission and through the EU statistics office, Eurostat and so on (European Commission, 2010: 3-4).

\section{THE SEVEN FLAGSHIPS}

The Commission initiated seven flagships to be implemented to provide for a smart, sustainable and inclusive European economy. It was declared that such flagships had to be focused on an integrated policy based on a European/EU and individual member state perspective (see Bongardt and Torres, 2010: 137; Armstrong, 2012: 288-9). The Europe 2020 communication identified the following flagships:

- 'Innovation Union' to improve framework conditions and access to finance for research and innovation so as to ensure that innovative ideas can be turned into products and services that create growth and jobs.

- 'Youth on the move' to enhance the performance of education systems and to facilitate the entry of young people to the labour market.

- 'A digital agenda for Europe' to speed up the roll-out of high-speed internet and reap the benefits of a digital single market for households and firms. 
- 'Resource efficient Europe' to help decouple economic growth from the use of resources, support the shift towards a low carbon economy, increase the use of renewable energy sources, modernize our transport sector and promote energy efficiency.

- 'An industrial policy for the globalization era' to improve the business environment, notably for SMEs, and to support the development of a strong and sustainable industrial base able to compete globally.

- 'An agenda for new skills and jobs' to modernize the labour market and empower people by developing their skills throughout the lifecycle with a view to increasing labour participation and better matching labour supply and demand, including through labour mobility.

- 'European platform against poverty' to ensure social and territorial cohesion such that the benefits of growth and jobs are widely shared and people experiencing poverty and social exclusion are enabled to live in dignity and take an active part in society. (European Commission, 2010: 3-4; see also Stec and Grzebyk, 2018: 123)

In the area of smart growth, the Commission identified three flagships of reforms in Innovation Union, Youth on the Move and a Digital Agenda for Europe. The flagship Innovation Union initiative focused on research and development and innovations to promote a transformation of Europe's economy away from industrialization based on oil and gas and towards a greener economy of energy and resource efficiency and new jobs, products and services based on high-tech reforms. Smart growth also embedded health and ageing and how to meet the demographic challenges that exist in Europe with a shrinking workforce and an ageing population that create dire straits for European welfare societies. The flagship Youth on the Move initiative focused on the importance of improved educational institutional capacities and European know-how and skills. This flagship sought to improve smart growth by improving higher education among European universities, enhance researchers' strategic programmes, promote increased mobility among students and trainees, facilitate improved chances among young Europeans to enter the labour market and gear learning outcomes in course syllabuses to contemporary labour market requirements. Finally, under the smart growth objective, the flagship Digital Agenda for Europe initiative focused on how to make use of digitalization, based on a digital single market to provide sustainable economic and social benefits through development of the use and supply of the Internet and broadband in an improved online infrastructure for all of Europe and for all Europeans. This required political and financial 
support for research, innovations and online services for private and public sector activities (European Commission, 2010: 10-12).

In the area of sustainable growth, the Commission pinpointed two flagships to focus on: the resource-efficient Europe initiative and the industrial policy for the globalization era initiative. The first flagship initiative stated the importance of transforming the European economy into a resource-efficient and low-carbon economy. Europe's economic growth had to be decoupled from inefficient resource and energy use and embed a sustainable approach that prioritized reduced $\mathrm{CO} 2$ emissions, while remaining competitive. The transformation to a greener economy should focus on the transport sector, on the road, in the air and at sea, including a change of the car industry in the production of electric and hybrid cars. The overall objective was to turn the European economy into a low-carbon economy with high emissions reduction providing for real measurements against global climate change. The second flagship on sustainable growth, in the industrial policy for the globalization era flagship initiative, addressed the economic recession and its impact on industries and SMEs in Europe, the competitiveness that comes with globalization and the demand to transform industries to meet climate change challenges. Although some sectors face major changes to survive in the market, other sectors may grow intensively by new market demands and technological solutions. The Commission set out to address the need for industrial transformation by supporting entrepreneurship and new ideas and innovations in a new industrial policy to assist the manufacturing and service industries to survive and develop a competitive and diversified base. The Europe 2020 communication also called for a reduction in transaction costs for businesses in Europe as well as in the administrative burden and dysfunctional business legislation, and improved access to finances, the Single Market and new markets internationally.

Finally, in the area of inclusive growth, two flagships were announced in the agenda for new skills and jobs and the European platform against poverty initiatives. The agenda for new skills and jobs flagship initiative focused on modernizing the labour market and consolidating the social model in the European economy by focusing on work hours, health issues, work safety and so on, as well as empowering Europeans with increased skills and know-how to lower the unemployment rate and make citizens prepared for new jobs and career changes as the economy is transforming. The Commission also stated the importance of providing financial support to promote intra-EU mobility, to assist in adjusting labour supply to labour demand in Europe and to promote improved cooperation between labour market institutions and social institutions in different member states and on national, regional and local levels. In 
addition, the Commission also focused on an overview of gender equality and existing work-life balance as well as tax levels and benefit systems to keep low-skilled people from social and economic marginalization and to encourage self-employment and entrepreneurship. The second initiative, the European platform against poverty, addressed measurements to combat poverty and socioeconomic marginalization and to promote integration. The Commission stressed the importance of cooperation between institutions, member state authorities and private actors to decrease social exclusion and to implement programmes for those at risk of poverty and/ or social exclusion by providing education, training and job opportunities among groups and in neighbourhoods in dire straits. Such an approach should also include reforms against discrimination based on disabilities, gender and/or migration (European Commission, 2010: 16-18).

The Europe 2020 strategy's main objectives and flagship initiatives are summarized in Box 1.1.

\section{EUROPE 2020: IMPLEMENTATION AND IMPACT?}

In 2014-15, the Commission conducted a mid-term review of Europe 2020 based on a public consultation of stakeholders' perceptions of the first years of Europe 2020 and lessons learned. Such consultation took place from May to October of 2014 (Eurostat, 2017: 17). It was summarized that the Europe 2020 strategy was viable and relevant and should continue to be the framework for promotion of growth, jobs and so on. Based on the mid-term review, the Commission initiated an assessment process named the European Semester to promote tighter alignment between the EU and individual member states (Gros and Roth, 2012: 79; Armstrong, 2012: 290). The European Semester policy cycle included several steps:

1. adoption of the Annual Growth Survey (AGS) by the Commission, identifying the socioeconomic priorities;

2. publication of the Commission's Alert Mechanism Report (AMR), but also the Joint Employment Report and recommendations to the Euro area;

3. publication of country reports to assist individual member states to launch reforms and initiatives to serve the Europe Agenda and reach national objectives;

4. submission of National Reform Programmes (NRPs) and Stability of Convergence Programmes (SCPs) from each individual member state, including measures and policies to implement country-specific recommendations from the Commission on a national basis; and 
5. adoption of recommendations from the Commission and the endorsement of such recommendations by the Council of Ministers and the Parliament. (Tusińska, 2016: 190-91; Zeitlin and Vanhercke, 2014: 3-4; Eurostat, 2017: 18-19)

The established European Semester was to focus on ensuring healthy public finances to limit macroeconomic inequalities and imbalances within the EU, promoting strategic investments, and assisting necessary structural reforms to seek new jobs and overall economic growth (European Commission, The European Semester). The main function of the Commission has been to analyse EU member states' overall progress and to provide individual national recommendations on macroeconomic and structural reforms and investments to be endorsed and adopted by the Council (European Commission, The European Semester, 2018). As stated,

Unlike the Europe 2020 strategy, the European semester has a stronger and more complete framework to monitor, discuss, evaluate and enforce policy goals set at the European level to achieve growth, competitiveness and stability in the EU. The European semester has thus been established to cover both the Europe 2020 and the overall economic situation in the member states, including the short-term challenges. (Gros and Roth, 2012: 79)

There has been great scholarly interest in discussing Europe 2020 and its core concepts, but foremost is forecasting whether the EU has been/can be successful in implementing some or all of Europe 2020's identified targets at one time or over a broader time range (Fura et al., 2017: 969-70). Such studies have focused on the different targets set out in Europe 2020 (see Moreno and García-Álvarez, 2018; Liobikienè and Butkus, 2017: 298-9; see also Fura et al., 2017; Renda, 2014; Gros and Roth, 2012; Theodoropoulou,

\section{BOX 1.1 AGENDA 2020}

- Raise the employment rate of the population aged $20-64$ from $69 \%$ to $75 \%$ or more.

- Achieve the target of investing 3\% of GDP in R\&D.

- Reduce greenhouse gas emissions by at least $20 \%$ compared to 1990 levels and increase the share of renewable energy in our final energy consumption to $20 \%$, and achieve a $20 \%$ increase in energy efficiency.

- Reduce the share of early school leavers to $10 \%$ from the current $15 \%$ and increase the share of the population aged 30-34 having completed tertiary education from $31 \%$ to at least $40 \%$.

- Reduce the number of Europeans living below national poverty lines by $25 \%$, lifting 20 million people out of poverty. 


\begin{tabular}{|c|c|c|}
\hline Smart Growth & Sustainable Growth & Inclusive Growth \\
\hline $\begin{array}{l}\text { Innovation } \\
\text { The EU's Innovation } \\
\text { Union flagship initiative } \\
\text { targeted improving } \\
\text { framework conditions } \\
\text { and access to finance } \\
\text { for research and } \\
\text { innovation so as } \\
\text { to strengthen the } \\
\text { innovation chain } \\
\text { and boost levels of } \\
\text { investment throughout } \\
\text { the Union. }\end{array}$ & $\begin{array}{l}\text { Climate, Energy And } \\
\text { Mobility } \\
\text { The EU's resource } \\
\text { efficient Europe } \\
\text { flagship initiative } \\
\text { targeted decoupling } \\
\text { economic growth from } \\
\text { the use of resources, } \\
\text { by decarbonizing our } \\
\text { economy, increasing } \\
\text { the use of renewable } \\
\text { sources, modernizing } \\
\text { our transport sector } \\
\text { and promoting energy } \\
\text { efficiency. }\end{array}$ & $\begin{array}{l}\text { Employment And Skills } \\
\text { The EU's agenda for } \\
\text { new skills and jobs } \\
\text { flagship initiative } \\
\text { targeted modernizing } \\
\text { labour markets by } \\
\text { facilitating labour } \\
\text { mobility and the } \\
\text { development of } \\
\text { skills throughout the } \\
\text { lifecycle with a view } \\
\text { to increasing labour } \\
\text { participation and better } \\
\text { matching labour supply } \\
\text { and demand. }\end{array}$ \\
\hline $\begin{array}{l}\text { Education } \\
\text { The EU's Youth on the } \\
\text { Move flagship initiative } \\
\text { targeted enhancing } \\
\text { the performance of } \\
\text { education systems } \\
\text { and reinforcing } \\
\text { the international } \\
\text { attractiveness of } \\
\text { Europe's higher } \\
\text { education institutions. }\end{array}$ & $\begin{array}{l}\text { Competitiveness } \\
\text { The EU's industrial policy } \\
\text { for the globalization era } \\
\text { flagship initiative was } \\
\text { designed to improve the } \\
\text { business environment, } \\
\text { especially for SMEs, } \\
\text { and to support the } \\
\text { development of a } \\
\text { strong and sustainable } \\
\text { industrial base able to } \\
\text { compete globally. }\end{array}$ & $\begin{array}{l}\text { Fighting Poverty } \\
\text { The EU's European } \\
\text { platform against poverty } \\
\text { flagship initiative was } \\
\text { designed to ensure } \\
\text { social and territorial } \\
\text { cohesion such that } \\
\text { the benefits of growth } \\
\text { and jobs are widely } \\
\text { shared and people } \\
\text { experiencing poverty } \\
\text { and social exclusion are } \\
\text { enabled to live in dignity } \\
\text { and take an active part } \\
\text { in society. }\end{array}$ \\
\hline $\begin{array}{l}\text { Digital Society } \\
\text { The EU's Digital Agenda } \\
\text { for Europe flagship } \\
\text { initiative targeted } \\
\text { speeding up the roll-out } \\
\text { of high-speed Internet } \\
\text { and reaping the benefits } \\
\text { of a digital single market } \\
\text { for households and } \\
\text { firms. }\end{array}$ & & \\
\hline
\end{tabular}

Note: Adapted from European Commission (2010, Annex I). 
2010). In 2014/2015, during the mid-term analysis of Europe 2020, the overall progress made on the objectives of the strategy was analysed.

First, focusing on employment and increasing the employment rate in the 20-64 age group had improved, but did not reach the 2020 target of 75 per cent. In 2015, the employment rate had increased to about 70 per cent. In 2008 , during the peak of the economic recession and preceding the Europe 2020 strategy, the employment rate for this age group had increased to 70.3 per cent. The ongoing economic crisis resulted in a declining employment rate to about 68.4 per cent in 2013. However, in 2015, the employment rate had increased again, symbolizing a possible turning point (Eurostat, 2017). In the latest Eurostat evaluation of progress made in 2017 (data on $2015 \mathrm{and} /$ or 2016), it was stated that the rate had increased to 71.1 per cent, showing a positive trend of growing employment and getting closer to the Europe 2020 target of 75 per cent. However, Eurostat indicated that there were higher unemployment rates for people aged 20-29 and people aged 55-64, those citizens with limited education, and migrants to the EU who became citizens, as well as an existing gender employment gap. In addition, Eurostat also addressed major imbalances in employment rates between EU member states, with a north-south division on a national and regional level, Sweden, Germany, Austria, the Netherlands and the UK having high levels of employment. For example, in 2016 employment in Greece was about 56.2 per cent compared to 80.1 per cent in Sweden (Eurostat, 2017: 8-9, 27, 30; see also Gros and Roth, 2012: 32-43). As stated, 'Northern and central European countries recorded the highest rates; eight countries even exceeded the $75 \%$ EU employment target. With employment rates below 65\%, Mediterranean countries dominated the lower end of the scale' (Eurostat, 2017: 30). Finally, there were also variations on employment rates based on age, gender, education and migration. In short, a general employment gap existed between the young and middle aged, men and women, educated and less educated people and natives and migrants, although in some cases, such as gender balance, the employment gap is decreasing (Eurostat, 2017: 29-33, 36-8).

Second, when studying progress made on research and development and the promoted objective to increase gross domestic expenditure on R\&D, Eurostat identified a minor increase as a percentage of GDP from 2008 and forward. In 2008, R\&D expenditure was 1.85 per cent of GDP and had increased to 2.03 per cent in 2014, indicating an increased level of public expenditure on R\&D. With the Europe 2020 stated objective of 3 per cent of GDP, the level reached in 2014 was 0.97 per cent below the identified objective (Eurostat, 2017: 57). In the latest evaluation of 2017, Eurostat expressed concerns for the continued low level of expenditure on research and development throughout the EU, at a level of about 2 per 
cent over some years. With a slowly rising level from 2008 and forward, statistics showed halted progress, with more or less status quo in level of investments between 2013 and 2015 (Eurostat, 2017: 10, 59). In a global comparison, the EU is behind the US, Japan, China and South Korea, advanced or fast developing economies, regarding R\&D. For example, in 2014, China passed the EU on percentage of GDP invested in R\&D. There are also regional variations within the EU with regions in Germany, the UK, Austria, France, Belgium and the Nordic countries with the highest levels of spending on R\&D. Within the EU, regions varied on R\&D intensity from 0.46 per cent to 3.26 per cent, with highest spending in regions in the Nordic countries and lowest in eastern and southern states such as Croatia and Romania (Gros and Roth, 2012: 9-10, 14-16; Eurostat, 2017: 59-61). As stated,

Estimates show that to meet the 2020 target, EU R\&D intensity would need to grow three times as fast as it did between 2007 and 2014 . . . According to these projections, if the 2007 to 2014 trend continues, investment in R\&D is forecasted to rise to only $2.28 \%$ by 2020 . . . Progressing more rapidly towards the 3\% target would require a faster structural shift to more knowledge-based economic activities. (Eurostat, 2017: 79)

Third, on climate change and energy, estimations of 2014 on greenhouse gas emissions showed a decline in the EU by 22.1 per cent compared to emission levels in 1990. In 2008-09, the emission level dropped sharply by 7.2 per cent, indicating a decline in the overall economic growth in Europe due to economic recession, but also a transformation into a greener European economy that has indicated a great opportunity not only to reach, but also to exceed the Europe 2020 target on greenhouse gas emissions (Eurostat, 2017: 85). Europe 2020 established 80 per cent, a drop of 20 per cent emissions in 2020, showing a successful EU strategy on greenhouse gas emissions. This has mostly been due to structural changes from a manufacturing-based economy to a service-oriented one, reduction in the use of coal in favour of gas and overall reductions of emissions in all sectors except transportation and aviation (Eurostat, 2017: 83-5). In a comparison between EU member states, Luxembourg scored best on reduction of emission per capita between 2005 and 2015, with good practice seen also in Denmark, Greece, Belgium, Finland and Cyprus and poor practice seen in eastern EU member states. In 2015, 16 out of 28 member states had reached their national objectives as set out in relation to Europe 2020 (Eurostat, 2017: 89-90; see also Liobikienè and Butkus, 2017: 299-305).

In addition, the share of renewable energy in gross final energy consumption increased between 2008 and 2014 from 11 per cent to 16 per 
cent due to biofuels and renewable waste, hydropower and wind, and solar energy. The Europe 2020 target of 20 per cent was not reached in 2014, falling 4 per cent behind in the share of renewable energy in gross final energy consumption, but with signs of fast progress. However, all EU member states have increased their levels of renewable energy, and ten member states have met their national objectives as set out in relation to Europe 2020 (Eurostat, 2017: 96). Another target is declining primary energy consumption. This consumption level had fallen between 2008 and 2014 by 11 per cent, leaving the oil consumption level in the EU lower than in 1990 and almost reaching the Europe 2020 objective by only falling 1.6 per cent below it (Eurostat, 2017). In the Eurostat assessment of 2017, a minor increase of emissions over the last few years was noted, but an overall significant decrease over time was observed, leaving the EU with a great chance to meet the Europe 2020 Agenda target of decreasing gas emissions by 20 per cent in 2020 - a target that had already been met in 2014 and now had to be consolidated. Eurostat explained this EU progress in terms of reduction of gas emission in all sectors except fuel combustion in transport and aviation as follows: 'The share of renewable energy in gross final energy production, the Europe 2020 strategy's second climate change and energy target, increased from 16.1 percent in 2014 to 16.7 percent in 2015. Therefore, the EU remains 3.3 percentage points below the Europe 2020 renewable energy target of 20 percent' (Eurostat, 2017: 10).

Fourth, on education and early leavers from education and training in the 18-24 age range, Eurostat indicated in 2008 a level of 14.7 per cent and in 201511 per cent, consistently closing on the Europe 2020 objective of 10 per cent. On tertiary education attainment in the 30-34 age group, Eurostat also identified a consistent increase from 2008 to 2015 from 31.1 per cent to 38.7 per cent, almost reaching the Europe 2020 objective of 40 per cent by 2020 (Eurostat, 2017: 109). The Eurostat analysis of 2017 showed a continued decline in number of early leavers, from 11 per cent in 2015 to 10.7 per cent in 2016, stating that 'Europe is steadily approaching its headline target for 2020, which envisages reducing the rate of early leavers from education and training to less than 10 percent' (Eurostat, 2017: 11; see also Gros and Roth, 2012: 44). It was also argued that women as early leavers were already below the target and that men, although lagging behind, are closing the gap. The most challenged groups were recent immigrants. Early leavers tend to be at a higher risk than others of becoming unemployed, with about 58 per cent of early leavers in the 18-24 age group being unemployed or inactive in 2016 (Eurostat, 2017: 11). In 2016, 15 EU member states had already reached their national objectives based on the Europe 2020 strategy and 17 states had reached the EU objective of 10 per cent, but variations existed among the other member 
states. In Luxembourg, Croatia, Lithuania, Poland and Slovenia, the early leavers were less than 6 per cent, compared to Malta, Romania and Spain with 18.5 per cent or even more, although such numbers were declining from previous years (Eurostat, 2017: 112; see also Istvan et al., 2016). In addition, younger people were generally more educated compared to older people, and migrants born outside the EU showed a lower level of education compared to European-born people in the EU. Member states also showed variations in the amount of money spent on education for their citizens. The highest public expenditures on education are found in Denmark and Sweden (8 per cent of GDP/7.7 per cent), compared to Romania (2.8 per cent) and Czech Republic (3.8 per cent) (Eurostat, 2017: 123). However, EU member states overall showed progress, as stated by Eurostat:

The EU average early school leaving rate in 2010 was 13.9 percent and would need to be below 10 percent by 2020 , ten years later. It follows from a basic calculation that the minimum annual progress required for the EU as a whole during this period is $-3.5 \%$, whereas the observed annual progress for the EU between 2010 and 2016 has been $-3.8 \%$. This means that overall the EU is on track. ... (Eurostat, 2017: 127)

Fifth and finally, focusing on people at risk of poverty and/or social exclusion, the economic crisis had a negative impact, leaving an increased number of people living at risk of poverty and/or social exclusion (see discussion by Gros and Roth, 2012: 56-62); from 118 million people in 2010 to 124 million in 2012. After a few years of crisis, a decline was recorded, leaving about 122 million Europeans at risk in 2014. That is almost one in four people in the EU, and 25 million people too many to reach the Europe 2020 objective (Eurostat, 2018b). In the Eurostat analysis of 2017, about 118.8 million people were affected, showing a decline in the number of people at risk (Eurostat, 2017: 133). The Europe 2020 target, however, was to decrease the number identified in 2008 by 20 million people, leaving the EU in 2017 still with a major challenge. As stated by Eurostat,

Although the share of poor or socially excluded people has recently decreased and is approaching the levels observed before the economic crisis in 2008, almost every fourth person (23.7 percent of the population) in the EU remained at risk of poverty or social exclusion in 2015, which means that the gap to the EU target was 22.9 million people. (Eurostat, 2017: 11)

Risk of social exclusion has embedded several related challenges, foremost in monetary poverty, but also material deprivation and low work intensity. While monetary poverty has slightly increased over time 
since 2010, with about 17.3 per cent of citizens challenged in 2015, people in households with low work intensity stayed more or less the same, with a decreased level of people with material deprivation. However, people at risk of poverty and social exclusion remained high in 2015: 86.6 million Europeans were at risk of monetary poverty, 40.3 million at risk of severe material deprivation and 39.6 million at risk of very low work intensity (Eurostat, 2017: 12, 132-6). As stated by Eurostat,

[t]he number of people living in poverty or social exclusion has fallen since the economy started recovering in 2013. Nevertheless, almost every fourth person in the EU still experiences at least one of the three forms of poverty or social exclusion, showing there is some way to go to meet the Europe 2020 Strategy target. (Eurostat, 2017: 132)

It should be stated that there is great variation within Europe on the risk of poverty and social exclusion. The Czech Republic (14 per cent), Sweden (16 per cent), the Netherlands (16.4 per cent) and Finland (16.8 per cent) scored lowest on risk in 2015, while some southern and eastern European EU member states such as Bulgaria (41.3 per cent), Romania (37.4 per cent) and Greece (35.7 per cent) scored highest, with about one-third or more of the population at great risk of poverty and/or social exclusion. Overall, in 201516 member states saw increased numbers of citizens facing poverty and/or social exclusion compared to 2008 , leaving these states far from their Europe 2020 national targets. The most negative trends were identified in Greece, Cyprus and Spain (Eurostat, 2017: 136-7). People's risk of poverty and social exclusion in EU member states was higher for women, the young, less-educated people and the unemployed. Although the gender gap has decreased on poverty, women's rate of being challenged by poverty or social exclusion was about 1.4 per cent higher than men's; 31.3 per cent of young people in the 18-24 age group were at risk, compared to 17.4 per cent among the elderly of 65 or older. The economic recession led to young people facing major challenges to enter the labour market or only finding poor-quality and low-paid jobs with temporary contracts. Migrants were another group at risk: native citizens of EU countries comprised 21.7 per cent of the at-risk population, with 25.2 per cent from other EU countries and an additional 40.2 per cent born outside the EU territory (Eurostat, 2017: 143; Chung et al., 2012: 301-306, 314).

The overall achievements made on Europe Agenda targets in 2015/2016 are summarized below in Table 1.2. It should, however, be stated that the implementation of Europe 2020 has varied between EU member states, with a great amount of implementation in Sweden, Finland, Denmark and 
Table 1.2 Europe 2020 targets, EU-28

\begin{tabular}{|c|c|c|c|c|c|c|c|c|}
\hline Topic & $\begin{array}{l}\text { Target } \\
\text { Indicator }\end{array}$ & 2008 & 2013 & 2014 & 2015 & 2016 & 2017 & Target \\
\hline Employment & $\begin{array}{l}\text { Employment } \\
\text { rate, age group } \\
20-64\end{array}$ & 70.3 & 68.4 & 69.2 & 70.1 & 71.1 & 72.2 & 75.0 \\
\hline $\mathrm{R} \& \mathrm{D}$ & $\begin{array}{l}\text { GDP on R\&D } \\
(\% / \text { GDP })\end{array}$ & 1.84 & 2.02 & 2.03 & 2.04 & 2.03 & - & 3.0 \\
\hline $\begin{array}{l}\text { Climate } \\
\quad \text { change \& } \\
\text { energy }\end{array}$ & $\begin{array}{l}\text { Greenhouse } \\
\text { gas emission }^{\mathrm{a}} \\
\text { (Index 1990: } \\
\text { 100) }\end{array}$ & 90.6 & 82.4 & 77.4 & 78.0 & 77.6 & - & 80.0 \\
\hline Education & $\begin{array}{l}\text { Early leavers } \\
\text { from education/ } \\
\text { training ( } \% \\
\text { of population } \\
\text { aged } 18-24)\end{array}$ & 14.7 & 11.9 & 11.2 & 11.0 & 10.7 & 10.6 & $<10.0$ \\
\hline $\begin{array}{l}\text { Poverty \& } \\
\quad \text { social } \\
\text { exclusion }\end{array}$ & $\begin{array}{l}\text { People at risk } \\
\text { of poverty } \\
\text { or social } \\
\text { exclusion, } \\
\text { EU-27 (million } \\
\text { people) }\end{array}$ & 116.1 & 121.6 & 120.8 & 117.8 & 116.9 & - & 96.2 \\
\hline
\end{tabular}

Note: a Total emission, including international aviation, but excluding emissions from land use, land use change and forestry.

Source: Adapted from Eurostat (2018a).

Austria and lower levels of implementation in Romania, Bulgaria, Italy, Malta, Spain and Greece (Stec and Grzebyk, 2018: 128-9).

The Eurostat statistics on progress made on Europe 2020 were summarized in the 2017 edition with the following:

Since 2008, substantial progress has been made in the area of climate change and energy through reduced greenhouse gas emissions and increased use of renewable energy sources. Positive developments are also visible in the area of education, where the EU is within reaching distance of both headline targets. While the EU remains at a significant distance from its targets on R\&D investment, employment and poverty alleviation, the most recent developments in the latter two areas are encouraging and the targets are still within reach for 2020. (Eurostat, 2017: 8)

Europe 2020 is soon to be concluded after a decade of embedded initiatives and flagships for European governance to be implemented. There 
have been discussions on the content and potential consequences of the agenda on European smart, sustainable and socially inclusive growth. Many scholars have addressed concerns over Europe 2020 based on the limited progress made from 2000 to 2010 and the Lisbon Strategy (see Tusińska, 2016; Makarovič et al., 2014; Gros and Roth, 2012; Prijon, 2012; Borghetto and Franchino, 2010). Many other scholars have provided different forecasts pointing out more or less progress to be expected on R\&D, employment, education, climate, poverty reduction and so on (see Gros and Roth, 2012: 2-4). Scholars have also shed light on potential hindrances to successfully implementing Europe 2020 (see Renda, 2014: 5-10; Budd, 2013: 285; Bongardt and Torres, 2010; Tilford and Whyte, 2010).

One such first obvious hindrance to the implementation of Europe 2020 has been the economic recession in Europe. The reason or context of the Commission Communication of 2010 was the global and European recession that had begun in 2007-08 (Bongardt and Torres, 2010: 136). The European economic crisis, which began in the US and spread around the world, challenged the EU, individual member states, regions and communities throughout Europe from 2009 forward. The economic recession influenced more or less all EU member states on a national, regional and local level and challenged political, economic and social survival in Cyprus, Greece, Portugal, Ireland and Spain, among other states. The severe negative impact of the economic crisis required immediate political and financial assistance to these member states from other EU member states, the European Central Bank (ECB) and the International Monetary Fund (IMF) among others. As a consequence of the economic recession, most EU member states faced declining growth, rising unemployment and social tension.

The economic crisis is still damaging European integration and prosperity. The Commission stated that the economic recession had not only halted European economic growth but also wiped out previous progress in Europe to such an extent that Europeans in 2010 were under severe political, economic and social stress. In a few years, European GDP had fallen by 4 per cent; industrial production levels were back to the levels of the 1990s; 23 million - about 10 per cent of the European active population - had faced unemployment; and public finances averaged a deficit of 7 per cent of GDP. In addition, the fragility of the financial system and the banking sector imposed serious restraints on companies and households to access money for investments, borrowing and spending, further paralyzing the European economy (European Commission, 2010: 5). The Commission argued how 20 years of European fiscal consolidation had been wiped out in two years of economic crisis: 
Europe faces a moment of transformation. The crisis has wiped out years of economic and social progress and exposed structural weaknesses in Europe's economy. In the meantime, the world is moving fast and long-term challenges - globalisation, pressure on resources, ageing - intensify. The EU must now take charge of its future. Europe can succeed if it acts collectively, as a Union. We need a strategy to help us come out stronger from the crisis and turn the EU into a smart, sustainable and inclusive economy delivering high levels of employment, productivity and social cohesion. Europe 2020 sets out a vision of Europe's social market economy for the 21st century. (European Commission, 2010: 3)

The Communication 'EUROPE 2020 - A strategy for smart, sustainable and inclusive growth' was not, however, 'only' a recovery plan to handle the immediate economic crisis, but also a strategy to identify and resolve what the Commission argued to be Europe's structural weaknesses. The Commission declared that Europe's economy had had challenges long before the economic crisis burst out and added that such structural challenges included (among others) a relatively low average growth rate compared to other regions around the world, low levels of investments in research and development, limited implementation of information and communications technologies, cultural reluctance to prioritize and embrace innovations, and a weakened business environment as well as existing obstacles to finding risk capital and entering new markets. Europe's economic structural weaknesses were especially alarming with the fast-developing global competitiveness from other economic regions around the world. The Commission pointed out that China and India, as economically dynamic actors with high levels of investments in research and technology and therefore competitors, were also potential markets for European investment and economic expansion. In addition, the remarkable economic progress showed by the G-20 has come to symbolize a new, fast-developing global economic order.

A second potential hindrance identified by scholars is the limited functions of EU governance. The way for Europe to handle growing global economic competition is to act together within the EU to solve shared problems, and by acting together, adding extra value to the global economy. As stated, 'The EU will influence global policy decisions only if it acts jointly. Stronger external representation will need to go hand in hand with stronger internal co-ordination' (European Commission, 2010: 6). The Communication clearly stated the importance of stronger cohesiveness within the Union to act as one global and regional actor. It stated the importance of multiple actors working towards a greater Europe of prosperity and democracy and how such efforts required strengthened internal coordination. In political science, the EU call for internal coordination 
has been referred to as European governance. European governance has been defined as a distinct form of political steering of European politics embedding networks of public and private actors that, in cooperation and competition, promote public policies towards common objectives. European governance has been defined as something very different from the traditional perspective on government with hierarchical steering based on centralized authority. The many references to the EU as governance is also present in Europe 2020. The agenda from the Commission calls upon all of Europe - European institutions, EU member states, regional and local authorities, as well as private actors and the civil society - to implement Europe 2020. The Commission also declares that all EU policies, instruments, judicial and financial instruments have to be mobilized to meet all the objectives set out in Europe 2020. It was stated that the Single Market is a vital instrument to promote the implementation of Europe 2020 and to ensure a future Europe of growth, job opportunities and prosperity.

One potential hindrance within Europe 2020 has been on the one hand the important role of the EU member states to implement policies to reach the objectives, and on the other hand the limited legitimacy and capacity of the Commission to convince all member states that embedded flagships and objectives are the most important ones. There seems to be a lack of member state commitment to Europe 2020 and an unwillingness to provide the Commission with authority to promote European objectives from a supranational level in favour of a strengthened and more active European Council (Becker et al., 2016: 1011-12). Based on experience from the Lisbon Strategy, the open method of coordination (OMC) has proven to be a fragile method due to the implied voluntary cooperation from member states and the non-existence of competences on the EU level. Different European member states have had different kinds of economic and social challenges to be tackled by other means than perhaps mentioned in Europe 2020. Some scholars have therefore argued that Europe 2020 requires an improved Annual Growth Survey by the Commission that more specifically points out national progress made and progress kept strictly related to the Europe 2020 targets. What has also been argued to be missing is a regional and local priority, with more resources and focus on subnational possibilities and problems rather than the three overall EU targets in smart, sustainable and socially inclusive growth. One such approach would be to break down overall EU objectives to subnational settings. As stated,

the belief that one central strategy can fit the entire European Union, with 27 disparate economies of different profiles and reform requirements, borders on a central-planning mentality that can only damage economic growth. Too 
often European policy-makers fall victim to the view that Europe is a uniform economy and that its member economies all behave in the same way. (Erixon, 2010: 31)

There has been reluctance among richer states to assist or bail out weaker states from their economic hardships. There are disparities in fundamental socioeconomic standards with imbalances between member states regarding resources, know-how and productivity, with a wide range of diversity on when and where to begin reforms to meet future targets (Fura et al., 2017: 976-7). All this has raised a debate on poor governance within the EU or on the fact that individual member states primarily seek their own interests and safeguard their own national policies (see Zaucha et al., 2014). The Europe 2020 initiative has therefore lacked real ownership on those levels where the targets were to be met through successful implementation. Stronger governance would be required between the EU, member states and subnational regions to address Europe 2020's targets rather than promoting a 'one-size-fits-all' policy (Pagliacci, 2017: 601-604, 615; Renda, 2014: 1-3; Budd, 2013: 284-6; Armstrong, 2012: 295-7; Walburn, 2010: 702; Warleigh-Lack, 2010: 299-300; Erixon, 2010: 29-37; Walden, 2010: 2). As stated,

Put simply, the governance of Europe 2020 is broken since member states have de facto and de jure no incentive to align their agendas to the target set by the strategy. This is confirmed by the absence of any reference to the agenda in the overwhelming majority of government plans at national and regional levels in the EU28. (Renda, 2014: 11)

A third potential obstacle for the implementation of Europe 2020 has been the lack of evaluation of why the preceding strategy failed and of the practical quality of the 2020 strategy. The Lisbon strategy had a limited effect on European economic growth and prosperity. It has been stated that not a single target was achieved in 2010, and regardless of the great economic crisis of 2008, many have argued that such targets would never have been reached without the economic crisis. Although there is no need to focus on the Lisbon Strategy, it has been argued that some of the targets in it have been reflected in the new Europe 2020 without any critical assessments of why such targets should be kept in a new strategy when the previous ones failed to be reached (Walburn, 2010: 700). Some previously failed targets have concerned public investments, research and development and the quality of jobs created. As argued by scholars,

The Europe 2020 Strategy is about improving EU competitiveness and achieving sustainable growth. It builds on the revised Lisbon Strategy with some 
reinforcement of economic policy cooperation but within the same governance framework. Yet the reformed Lisbon Strategy of 2005 did not produce results in terms of undoing the large persisting differences between member states in the implementation of Lisbon goals. (Bongardt and Torres, 2010: 140)

In addition, critical arguments have also exposed how the flagship initiatives have been implemented in isolation from each other, missing out on significant synergies between, for instance, a greener economy and new products, digitalization and new jobs, education and social inclusion, and so on, leaving Europe 2020 more a group of fragmented initiatives rather than a comprehensive, integrated framework of reforms. It has also been pointed out how EU policies have too often missed out on referring to the targets set out in Europe 2020 and/or have had limited ties to such targets, leaving the different initiatives as set out in Europe 2020 marginalized from the EU policy process. For instance, there has been a lack of critical assessments and recommendations on how to tackle the tension between promoting economic growth for prosperity and social cohesion and a sustainable, greener economy with reduced greenhouse gas emissions. Europe 2020 states the importance of smart growth, but it has been argued that this concept has been poorly defined; in addition, how Europe is to decouple growth from emissions needs to be addressed. It has also been argued that the flagships have been far too limited in scope to address the real challenges in building smart, sustainable and socially inclusive growth in Europe. While some flagships have already been fully implemented, the Europe 2020 targets have not been reached and challenges remain. This has been argued to be a major symbol of imperfect (or at least inadequate) measures to solve existing problems (see Daly, 2012).

\section{STRUCTURE OF THE STUDY}

This study explores the Europe 2020 strategy and the role of European political entrepreneurship in debating, shaping and implementing it within the EU. The main idea is to explore the content of, conditions for and consequences of Europe 2020 by analysing the strategy for a future prosperous EU economy. The main focus is on European political entrepreneurship and how the strategy has been debated, decided on and implemented from a European governance perspective. The overall objective of this chapter has been to introduce the 2020 strategy to readers to become a platform for the chapters to come on analysing Europe 2020 and smart, sustainable and inclusive growth.

The Europe 2020 strategy called for major reforms on smart, sustainable 
and socially inclusive growth. The strategy also called for European leadership and new, bold, innovative and ambitious ideas on political entrepreneurship to help Europe become economically and socially great again. In contrast to other studies on European entrepreneurship, this study embeds a focus on potential and existing European political entrepreneurship aiming for growth and employment in Europe. It addresses the political entrepreneurial activities beyond day-to-day activities that challenge and change traditional institutions to favour entrepreneurship for smart, sustainable and socially inclusive growth. The first part of the book addresses the context and content of Europe 2020, with a focus on European governance and political entrepreneurship. It also sheds light upon what the EU wants to pursue through Europe 2020 in a socialeconomic model for the 21 st century (see Chapter 2). The first part is followed by Part II, which addresses core European actors to implement the initiative by the Commission on Europe 2020 in the European Council, the Council of the EU, the European Parliament, local and regional actors as well as EU agencies. Part III focuses on policies on smart, sustainable and socially inclusive growth by discussing competitiveness and industrial policies, research and innovation, gender equality policy, asylum and migration policy, and environmental and climate policy. The final part, Part IV, concludes and discusses the state of the EU and Europe beyond 2020.

\section{REFERENCES}

Armstrong, K.A. (2012). 'EU social policy and the governance architecture of Europe 2020'. Transfer, 18(3): 285-300.

Barbier, J.C. (2011). Changes in Political Discourse from the Lisbon Strategy to Europe 2020: Tracing the Fate of 'Social Policy'. European Trade Union Institute (ETUI). Brussels: ETUI.

Barroso, J.M. (2010). 'Preface' in Com 2020. Communication from the Commission: Europe 2020: A Strategy for Smart, Sustainable and Inclusive Growth. Brussels, 3.3.2010. Brussels: European Commission.

Baumol, W.J. (1990). 'Entrepreneurship: productive, unproductive and destructive'. Journal of Political Economy, 98(5): 893-921.

Becker, S., M.W. Bauer, S. Connolly and H. Kassim (2016). 'The Commission: boxed in and constrained, but still an engine of integration'. West European Politics, 39(5): 1011-31.

Bongardt, A. and F. Torres (2010). 'Europe 2020 - a promising strategy?' Intereconomics, 2010(3): 136-41.

Borghetto, E. and F. Franchino (2010). 'The role of subnational authorities in the implementation of EU directives'. Journal of European Public Policy, 17(6): 759-80.

Borzaga, C., G. Galera and R. Nogales (eds) (2008). Social Enterprise: A New 
Model for Poverty Reduction and Employment Generation - An Examination of the Concept and Practice in Europe and the Commonwealth of Independent States. UNDP Regional Bureau for Europe and the Commonwealth of Independent States.

Boyett, I. (1996). 'The public sector entrepreneur - a definition'. International Journal of Public Sector Management, 9(2): 36-51.

Brickerhoff, P.C. (2000). Social Entrepreneurship - The Art of Mission-Based Venture Development. New York: John Wiley and Sons.

Budd, L. (2013). 'EUROPE 2020: a strategy in search of a regional policy rationale?' Policy Studies, 34(3): 274-90.

Carroll, J.J. (2017). 'Failure is an option: the entrepreneurial governance framework'. Journal of Entrepreneurship and Public Policy, 6(1): 108-26.

Casson, M.C. (1995). Entrepreneurship and Business Culture. Aldershot, UK and Brookfield, VT, USA: Edward Elgar Publishing.

Chung, H., S. Bekker and H. Houwing (2012). 'Young people and the postrecession labour market in the context of Europe 2020'. Transfer, 18(3): 301-17.

Cross, D.M.K. (2017). The Politics of Crisis in Europe. Cambridge: Cambridge University Press.

Dahl, R.A. (1974). Who Governs? Democracy and Power in an American City. New Haven: Yale University Press.

Daly, M. (2012). 'Paradigm in EU social policy: a critical account of Europe 2020'. Transfer, 18(3): 273-84.

Erixon, F. (2010). 'The Europe 2020 strategy: time for Europe to think again'. European View, 9(June): 29-37.

EUR-Lex: Distribution of Competences (2018). Accessed 8 May 2018 at https:// eur-lex.europa.eu/summary/glossary/competences.html?locale=en.

EUR-Lex: OMC (Open Method of Coordination) (2018). Accessed 8 May 2018 at https://eur-lex.europa.eu/summary/glossary/open_method_coordination.html.

European Commission (2010). Communication from the Commission: Europe 2020: A Strategy for Smart, Sustainable and Inclusive Growth. Brussels, 3.3.2010. Brussels: European Commission.

European Commission, The European Semester (2018). Accessed 2 February 2018 at https://ec.europa.eu/info/business-economy-euro/economic-and-fiscalpolicy-coordination/eu-economic-governance-monitoring-prevention-correcti on/european-semester_en.

Eurostat (2017). Smarter, Greener, More Inclusive? Indicators to Support the Europe 2020 Strategy: 2017 edn. Luxembourg: Publications Office of the European Union.

Eurostat (2018a). Smarter, Greener, More Inclusive? Indicators to Support the Europe 2020 Strategy: 2018 edn. Luxembourg: Publications Office of the European Union.

Eurostat (2018b). Europe 2020 indicators: Poverty and social exclusion. Accessed January 2019 at https://ec.europa.eu/eurostat/statistics-explained/index.php/ Europe_2020_indicators_-_poverty_and_social_exclusion.

Finnemore, M. and K. Sikkink (1998). 'International norm dynamics and political change'. International Organizations, 52(4): 887-917.

Fura, B., J. Wojnar and B. Kasprzyk (2017). 'Ranking and classification of EU countries regarding their levels of implementation of the Europe 2020 strategy'. Journal of Cleaner Production, 165: 968-79.

Gawell, M., B. Johannisson and M. Lundqvist (2009). Samhällets Entreprenörer 
- En Forskarantologi om Samhällsentreprenörskap [Social Entrepreneurs - A Research Anthology on Social Entrepreneurship]. Stockholm: KK-stiftelsen.

Gros, D. and F. Roth (2012). The Europe 2020 Strategy - Can it Maintain the EU'S Competitiveness in the World?. Brussels: Centre for European Policy Studies (CEPS).

Hix, S. and K.H. Goetz (2000). 'Introduction: European integration and national political systems'. West European Politics, 23(4): 52-72.

Hoedl, E. (2011). 'Europe 2020 strategy and European recovery'. Problems of Sustainable Development, 6(2): 11-18.

Holcombe, R.G. (2002). 'Political entrepreneurship and the democratic allocation of economic resources'. The Review of Austrian Economics, 15(2/3): 143-59.

Hudrliková, L. (2013). 'Composite indicators as a useful tool for international comparison: the Europe 2020 example'. Prague Economic Papers, 4: 459-73.

Istvan, L., D. Eva and N.T. Orsolya (2016). 'Competitiveness - higher education'. Studia Universitatis Economics Series, 26(1): 11-25.

Jones, P. (1978). 'The appeal of the political entrepreneur'. British Journal of Political Science, 8(4): 498-504.

Kaiser, C.P. (1990). 'Entrepreneurship and resource allocation'. Eastern Economic Journal, 16(1): 9-20.

Karlsson, C., C. Silander and D. Silander (eds) (2016). Political Entrepreneurship for Regional Growth and Entrepreneurial Diversity: the Case of Sweden. Cheltenham, UK and Northampton, MA, USA: Edward Elgar Publishing.

Karlsson, C., C. Silander and D. Silander (eds) (2018). Governance and Political Entrepreneurship in Europe: Promoting Growth and Welfare in Times of Crisis. Cheltenham, UK and Northampton, MA, USA: Edward Elgar Publishing.

Kingdon, J. (1995). Agendas, Alternatives, and Public Policies. New York: HarperCollins.

Kotz, H.H. (2005). 'The Lisbon Agenda. On getting Europe back on track', in R. Caesar, K. Lammers and H-E. Scharrer (eds), Europa auf dem Weg zum Wettbewerbsfähigsten und Dynamischsten Wirtschaftsraum der Welt?, No. 76. Baden-Baden: HWWA Studies.

Liobikienè, G. and M. Butkus (2017). 'The European Union possibilities to achieve targets of Europe 2020 and Paris agreement climate policy', Renewable Energy, 106: 298-309.

Lisbon Treaty (2009). Accessed 8 May 2018 at http://www.lisbon-treaty.org/wcm/ the-lisbon-treaty.html.

Makarovič, M., J. Šušteršič and B. Rončević (2014). 'Is Europe 2020 set to fail? The cultural political economy of the EU grand strategies'. European Planning Studies, 22(3): 610-26.

McCaffrey, M. and J.T. Salerno (2011). 'A theory of political entrepreneurship'. Modern Economy, 2(4): 552-60.

Moreno, B. and M.T. García-Álvarez (2018). 'Measuring the progress towards a resource-efficient European Union under the Europe 2020 strategy'. Journal of Cleaner Production, 170: 991-1005.

Morgan, G. (1986). Images of Organizations. Los Angeles: Sage Publications.

Nakamura, R.T. and F. Smallwood (1980). The Politics of Policy Implementation. New York: St Martin's Press.

North, D.C. (1990). Institutions, Institutional Change and Economic Performance. Cambridge: Cambridge University Press. 
Osborne, D. and P. Plastrik(1993). Reinventing Government: How the Entrepreneurial Spirit Is Transforming the Public Sector. New York: Penguin Books.

Ostrom, E. (1965). Public Entrepreneurship: A Case Study in Ground Water Basin Management. Los Angeles: University of California, Los Angeles (UCLA).

Pagliacci, F. (2017). 'Regional paths towards Europe 2020 targets: a spatial approach'. European Planning Studies, 25(4): 601-19.

Prijon, L. (2012). 'Clientelism and Slovenian public administration reform'. Polish Sociological Review, 180(4): 545-60.

Putnam, R. (1993). Making Democracy Work - Civic Traditions in Modern Italy. Princeton, NJ: Princeton University Press.

Renda, A. (2014). The Review of the Europe 2020 Strategy: From Austerity to Prosperity? CEPS Policy Brief, No. 322: 1-13.

Roberts, N.C. and P.J. King (1991). 'Policy entrepreneurs: their activity structure and function in the policy process'. Journal of Public Administration Research and Theory, 1(2): 147-75.

Salerno, J.T. (2008). 'The entrepreneur: real and imagined'. Quarterly Journal of Austrian Economics, 11(3): 188-207.

Scheingate, A.D. (2003). 'Political entrepreneurship, institutional change and American political development'. Studies in American Political Development, 17(2): 185-203.

Schneider, M. and P. Teske (1992). 'Toward a theory of the political entrepreneur: evidence from local government'. American Political Science Review, 86(3): $737-47$.

Schumpeter, J.A. (1934). The Theory of Economic Development: An Inquiry into Profits, Capital, Credit, Interest, and the Business Cycle. Cambridge: Harvard University Press.

Silander, D. (2016). 'The political entrepreneur', in C. Karlsson, C. Silander and D. Silander (eds), Political Entrepreneurship: Regional Growth and Entrepreneurial Diversity in Sweden. Cheltenham, UK and Northampton, MA, USA: Edward Elgar Publishing, pp. 7-20.

Silander, D. (2018). 'European governance and political entrepreneurship in times of economic crisis', in C. Karlsson, C. Silander and D. Silander (eds), Governance and Political Entrepreneurship in Europe: Promoting Growth and Welfare in Times of Crisis. Cheltenham, UK and Northampton, MA, USA: Edward Elgar Publishing, pp. 3-24.

Silander, D. and C. Silander (eds) (2015). Politiskt Entreprenörskap - Den Offentliga Sektorns Sätt att Skapa Bättre Förutsättningar för Entreprenörskap Lokalt, Regional och Nationellt [Political Entrepreneurship - The Public Sector and Measurements to Improve Conditions for Entrepreneurship on Local, Regional and National Level]. Stockholm: Santérus förlag.

Simmons, R.T., R.M. Yonk and D.W. Thomas (2011). 'Bootleggers, baptists, and political entrepreneurs - key players in the rational game and morality play of regulatory politics'. The Independent Review, 15(3): 367-81.

Stec, M. and M. Grzebyk (2018). 'The implementation of the Strategy Europe 2020 objectives in European Union countries: the concept analysis and statistical evaluation'. Quality \& Quantity, 52(1): 119-33.

Theodoropoulou, S. (2010). 'Skills and education for growth and well-being in Europe 2020: are we on the right path?' EPC Issue Paper No. 61: 5-31. European Political Economy Programme. 
Tilford, S. and P. Whyte (2010). The Lisbon Scorecard X. Brussels: Centre for Economic Reform.

Tusińska, M. (2016). 'Competitiveness of the European Union - expectations, reality and challenges towards 2020'. Horizons of Politics, 7(21): 185-204.

Walburn, D. (2010). 'Europe 2020'. Local Economy, 25(8): 699-702.

Walden, W. (2010). 'Europe 2020 and beyond'. European View, 9: 1-3.

Wandel, J. (2016). 'The role of government and markets in the strategy "Europe 2020 " of the European Union: a robust political economy analysis'. International Journal of Management and Economics, 49(January-March): 7-33.

Warleigh-Lack, A. (2010). 'Greening the European Union for legitimacy? A cautionary reading of Europe 2020'. Innovation - The European Journal of Social Science Research, 23(4): 297-311.

Zaucha, J., T. Komornicki, K. Böhme, D. Swiatek and P. Zuber (2014). 'Territorial keys for bringing closer the territorial agenda of the EU and Europe 2020'. European Planning Studies, 22(2): 246-67.

Zeitlin, J. and B. Vanhercke (2014). 'Socializing the European semester? Economic governance and social policy coordination in Europe 2020'. Brown University, The Watson Institute for International Studies Research Paper No. 2014-17. 